\title{
塗床における下地凹凸と床表面凹凸発生との関係および 下地凹凸許容量設定の可能性に関する基礎的検討 FUNDAMENTAL STUDY ON A RELATION BETWEEN UNEVENNESS OF SUBSTRATUM AND THAT OF COATING FLOORS SURFACE, AND POSSIBILITY ABOUT ESTABLISHING AN ALLOWABLE LIMIT OF UNEVENNESS OF SUBSTRATUM
}

\author{
小野英哲*, 竹田智英**, 高橋宏 樹*** \\ Hidenori ONO, Tomohide TAKEDA and Hiroki TAKAHASHI
}

\begin{abstract}
This is the fundamental study about the unevenness of coating floors surface caused by that of substratum.

First, 9 substratum boards each having 12 holes with different size (depth and diameter) as unevenness of substratum were coated with 3 kinds of coating floors materials in 3 kinds of thickness.

Second, the depis (or height) of each surface unevenness grown on coating floors were measurer arid iclation between depth and size of holes of substratum were discussed.

Finally, an allowable limit of unevenness of substratum to make surface of coating floors even was established as an example.
\end{abstract}

Keywords : coating floors, unevenness, substratum, thickness

塗床, 凹凸, 下地, 塗厚

1 序

塗床においては，硬化前の塗床材料自体が持つセルフ レベリング性により，下地に多少の凹凸があっても平滑 な床表面が得られると考えられがちである。しかし，実 際には床表面に凹凸が発生し，様々な問題を誘発する原 因となっているのではないか，との疑問も提起されてい る。

一方, 下地凹凸之床表面凹凸発生之に関する客観的知 見は，凹凸が発生する，発生しないなどの段階をも含め て十分ではなく，塗床に対するより精緻な表面精度が要 求される現在，基礎的段階からの知見の集積が必要とさ れている。

本研究は，塗床におりる下地凹凸と床表面凹凸発生之 の因果関係を定性的に明らかにするとともに，発生する 凹凸の不都合さおよび下地凹凸の許容量の設定の可能性 に関して基礎的検討を行ったものであり，一部は日本建 築学会大会に報告している ${ }^{1)}$ 。

\section{2 本研究の目的および範囲}

本研究のおもな目的はつぎの二つである。

（）下地凹凸が床表面凹凸発生および凹凸の程度に影響を 与えるか否かを確認すること。

（）床表面凹凸の不都合さの程度を尺度化することが可能 かどうか，また不都合さと下地凹凸との関係を把握で きるかどうか，さらに両者の関係から下地凹凸の許容 量を設定できるかどうかの可能性を確認すること。 それ故, 下地凹凸の形状，寸法，塗床の種類，施工方 法，施工時の環境条件，不都合さの観点などに関しては， 確認する上で必要最小限に単純化することとし, 実際と の厳密な対応，さらには凹凸発生のメカニズムの究明な どは本研究の結果をもとに次の段階で綿密に検討するこ ととする。

下地凹凸と床表面凹凸発生との関係に関する客観的知

\footnotetext{
$*$ 東京工業大学工学部建築学科 教授 $\cdot$ 工博

** 東京工業大学工学部建築学科 大学院生

*** 東京工業大学工学部建築学科 助手 $\cdot$ 体育修
}

Prof., Dept. of Architecture and Building Engineering, Faculty of Engineering, Tokyo Institute of Technology, Dr. Eng.

Graduate Student, Dept. of Architecture and Building Engineering, Faculty of Engineering, Tokyo Institute of Technology.

Research Assoc., Dept. of Architecture and Building Engineering, Faculty of Engineering, Tokyo Institute of Technology, M. Phys. Educ. 
見が全く公表されていない状況で，基礎的とはいえ本研 究の目的を達成することは，下地の表面精度の重要性の 確認および塗床の表面精度の向上策検討のために十分有 意義であると考える。

以上から，本研究で対象とする下地凹凸は，例えばコ ンクリート下地における鏝むら，タンピングむら，押さ えむら，下地板類におけるそり，波うち，欠損，などの 局部的な凹凸をモデル化したものとし，塗床材料および 施工方法は一般的なものとする。なお，うねり，不陸， 撓み，などで表現される大きな広がりをるつ下地の非平 坦性に関しては，下地の表面精度以外に下地としての構 造上の問題なども加味されると考えられるので，本研究 の段階では研究の対象外とする。

また不都合さの観点としては，最も一般的でかつ誰も が認識できる観点のなかから，代表的な一つを取り上げ ることとする。

\section{3 既往の研究}

塗床表面凹凸発生に関する知見として，ふくれ，はが れなどについては数多く公表されているが，下地凹凸と 床表面凹凸発生との関係を究明した例は公表されていな い。また，床表面凹凸の測定方法は種々提示されている が，凹凸を評価する妥当性のある客観的な指標はこれま で提示されているとはいい難い。

\section{4 研究方法の概要}

研究方法の概要はつぎの通りである。

（1）下地凹凸之床表面凹凸発生とに関する実験的検討

（イ）凹凸を設けた下地試料を作成し塗床を施工す る。

（口）塗床の硬化後, 床表面凹凸発生を確認すると ともに，凹凸を測定する。

（八）床表面凹凸と下地凹凸，塗厚などとの対応を 検討する。

（2）床表面凹凸の不都合さの尺度化および下地凹凸の 許容量設定の可能性の検討

（イ）床表面凹凸についてあるひとつの観点からの 評価尺度の構成を試みるとともに，評価尺度 と床表面凹凸との関係から，床表面凹凸の限 界值の設定を試みる。

（口）床表面凹凸の限界值に対応する下地凹凸の許 容量の設定を試みる。

5 下地凹凸と床表面凹凸発生とに関する実験的検討 5.1 塗床の選択
我が国において一般的に用いられる塗床には，有機材 料系としてウレタン樹脂系, エポキシ樹脂系, ポリエス テル樹脂系，メタクリル樹脂系，アクリル樹脂系などが, 無機材料亲としてセメント系などが挙げられ，床の用途， 要求される性能などに応して選択，施工されている。本 研究の段階では塗床ごとの差を究明することを目的とは していないのでここれらのうち最も代表的とされている “片キシ樹脂系, ウレタン樹脂系, メタクリル樹脂系の 3つの単層の塗床で，表 1 に示すように，ごく一般的な 仕様をもつものを対象とすることとした。

なお下地平坦部における塗厚としては $1,2,3 \mathrm{~mm} の 3$ 種 を設定じた。

\section{2 下地試料の設定}

一般的に塗床はコンクリート下地や鋼板あるいは合板 下地に施工されることが多いが，水や気泡の侵入などの 凹凸以外の要因を排除すること, 塗床施工時の撓み，そ り発生などに対し十分な剛性を有しかつ加工性に優九て いること, 塗床材料との化学反応が生じないことなどの 理由から，塗床を施工する下地材料として $500 \mathrm{~mm} \times 500 \mathrm{~mm}$ $x .15 \mathrm{~mm}$ 平坦なアクリル板を用いることとした。

図 1 に下地試料の概要を示す。

表 1 塗床材料の仕様

\begin{tabular}{|c|c|c|c|c|}
\hline & 収縮率 & 硬化時間 & 色 & $\begin{array}{l}\text { 光沢度 } \\
\text { (実測値) }\end{array}$ \\
\hline エポキシ樹脂 & $\begin{array}{l}1.61 \% \\
(\text { (容積) }\end{array}$ & $\begin{array}{c}\text { 12時間 } \\
\text { (歩行可能) }\end{array}$ & 淡緑色 & 85.1 \\
\hline メタクリル樹脂 & $\begin{array}{l}0.10 \% \\
\text { (容積) }\end{array}$ & $\begin{array}{l}30 \sim 55 \text { 分 } \\
\text { (步行可能) }\end{array}$ & 黄色 & 16.7 \\
\hline ウレタン樹脂 & $\begin{array}{l}0.94 \% \\
(\text { 線) }\end{array}$ & $\begin{array}{c}12 \text { 時間 } \\
\text { (指触可能) }\end{array}$ & 淡黄色 & 54.8 \\
\hline
\end{tabular}
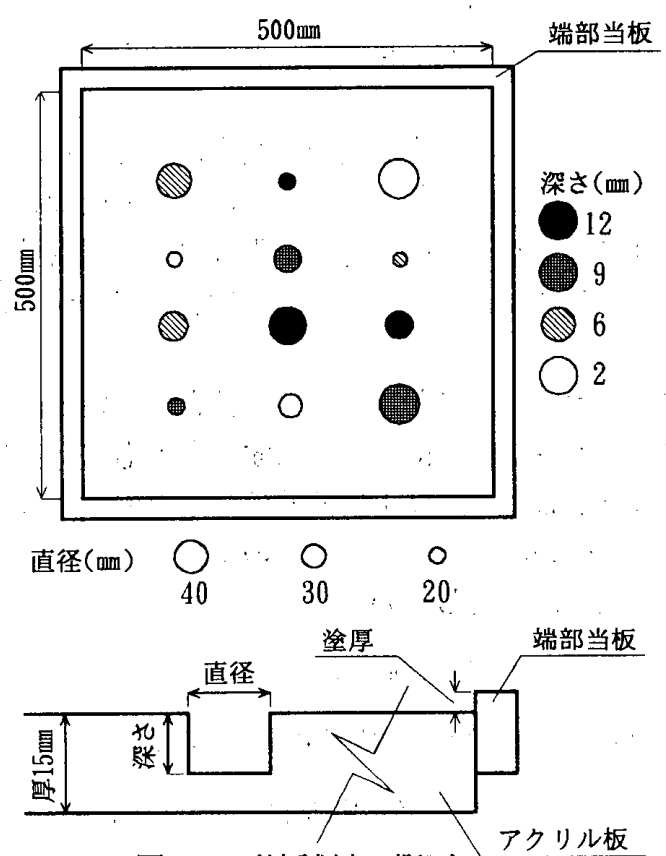

図 1 下地試料の概要 
下地試料の凹凸はアクリル板に設ける凹部によって具 現することとし, 予備実験さらには実際の下地の観察結 果などを踏まえて, 凹部の直径は $20,30,40 \mathrm{~mm}$ の 3 種, 深 さは各々の直径につき $2,6,9,12 \mathrm{~mm}$ の 4 種, 計 12 種とした。 また凹部間の間隔および下地試料の端部から凹部までの 間隔が床表面凹凸の発生に影響を与えないように，凹部 間の間隔は中心間で $90 \mathrm{~mm}$ 以上, 端部より凹部中心までの 距離は1 $15 \mathrm{~mm}$ とした。また各凹部の配置は，施工時の不 規則性を確保するために図 1 に示すように不規則なもの とした。

以上のように設定したアクリル板の周囲には, 塗厚と 同じ高さの当て板を設け, 総計 9 枚（塗床 3 種 $\times$ 塗厚 3 種）の下地試料を設定した。

\section{3 . 塗床の施工}

塗床の施工においては, 通常プライマーを塗布して下 地の表面を調整するが，本研究の下地はアクリル板のた め調整の必要がないことから, プライマー処理はせず, 3 種の塗床を代表的な工法である流し展へ工法により下 地試料に直接施工した。具体的には塗厚の基準となる当 て板よりあふれる量の樹脂を流し込み, 当て板の高さで 均すこととした。なお技能の差異による施工むらを極力 防ぐために, 全試料を一人の優れた技能工により施工し た。施工は屋内で, 温度, 湿度はそれぞれ $18.0^{\circ} \mathrm{C} \pm$ $0.5^{\circ} \mathrm{C}, 46 \% \pm 1 \% \mathrm{RH}$ である。

\section{4 塗床施工後の経過}

施工直後は各塗床試料とも表面は平坦で凹凸の発生は 視覚では認められず，塗床材料のセルフレベリング性が 確認された。しかし硬化に伴い，写真 1 に示した例のよ うに, 各塗床試料表面に下地試料の凹部之同様の形状を もつ円形の凹凸を生じた。なお各塗床試料とも下地試料 に凹部のない箇所には凹凸が生しなかった。

以下に各塗床ごとの硬化の経過を視覚により観察した 結果の詳細を記す。

エポキシ樹脂系塗床試料の場合は, 施工後 1 時間程度 から下地試料の凹部上に凹を生じ始め，以後凹は消える ことなく硬化した。

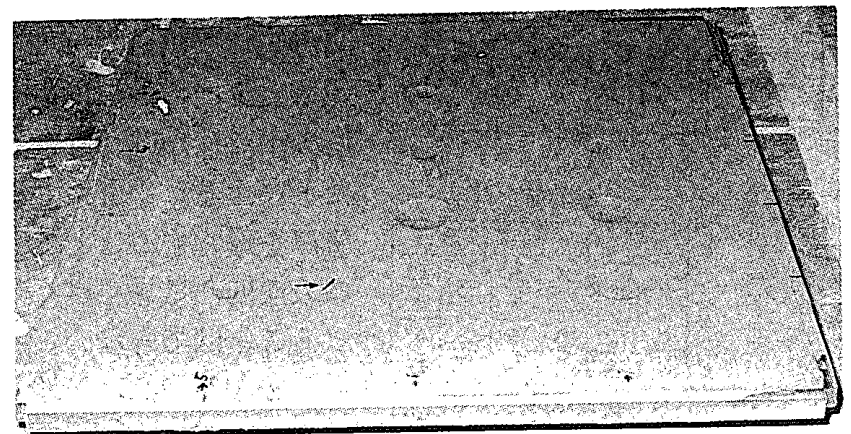

写真 1 硬化時の床表面凹凸発生状況例 （メタクリル樹脂 塗厚 $1 \mathrm{~mm} の$ 場合）
メタクリル榯脂系塗床試料の場合は施工数分後から工 ポキシ樹脂系塗床と同様に凹を生じ始め，凹を残したま ま硬化した。また両者の場合ともに下地試料の凹部の梁 い箇所から凹を生じ始めたことが視覚的に確認されたが、 凹部の深さが同じであれば凹の生じ始める時間に塗厚に よる大きな差は認められなかった。

ウレタン樹脂系塗床試料の場合は, 施工直後から樹脂 の筧拌時に混入したとみなせる小さな気泡痕が塗床試料 表面全体に生じ, さらに一時間程度経過後から下地試料 の凹部上に凸を生じ，そのまま硬化した。

5.5 下地凹凸之床表面凹凸発生とに関する基礎的考察

\subsection{1 床表面凹凸の測定}

下地試料凹凸之床試料表面凹凸とのおおよその関係を 検討する目的で，硬化終了後の塗床試料表面に発生した 凹凸の断面形状をレーザー変位計を用いて測定すること とした。図 2 に測定状況の概要を示す。レーザーの水平 方向の移動速度は $10 \mathrm{~cm} / \mathrm{s}$, 照射距離は $5 \mathrm{~cm}$ とし, 得られ

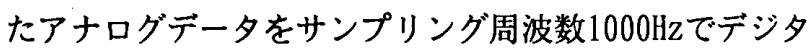
ル化し解析に供した。

なお測定は図 2 に示すように下地試料の凹部の中心を 通る直線に沿って行った。

得られた床表面凹凸の断面形状を示す曲線の例を図 3 に示す。得られた曲線には本研究の段階では不必要と考

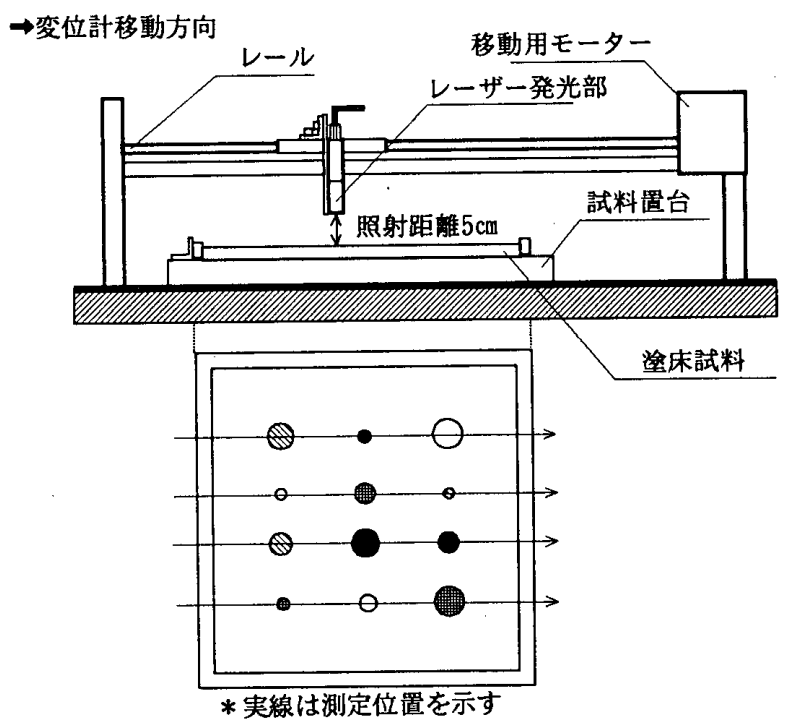

図 2 床表面凹凸の測定状況の概要

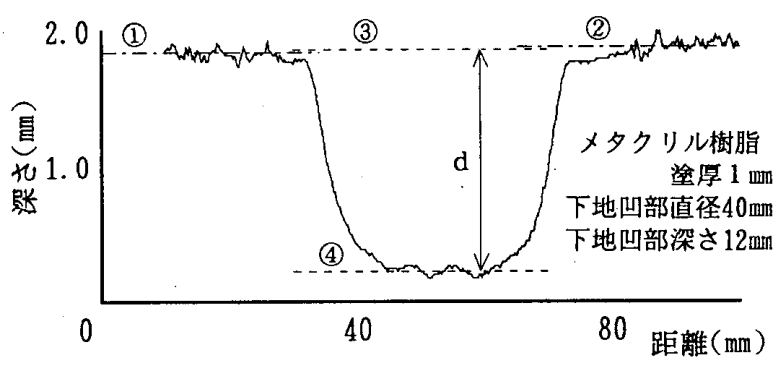

図 3 床表面凹凸の断面形状曲線の例 
えられる微少な凹凸があるため，以下の手順により単純 化して塗床試料表面凹凸量を求めることとした(図 3 参 照)。

（1）塗床試料表面凹（凸）部の両側の中心線(1)・(2)を 求め, 両者の中間の線を(3)とする。

（2）凹（凸）部底部の中心線(4)を求める。

（3）(3)亡(4)との距離 $\mathrm{d}$ を凹（凸）量とする。

なお中心線は，凹凸の形状を示す曲線のうち，取り出 した区間の面積をほぼ等分する直線とした。

以上本項で定義した塗床試料表面凹（凸）量は，本研 究の目的の範囲においてのみ有効であり，凹凸全体に対 し，普遍しようとしているものではないことを付記する。 5.5 .2 . 考察

図 4 に床下地凹量, 塗厚, および凹部直径と塗床試料 表面凹凸量との関係を示す。なお図において負(一)はへ こみ(凹)を正 $(+$ )はふく机(凸)を意味する。

図 4(A)から, エポキシ樹脂系塗床, メタクリル樹脂 系塗床では，凹部の深さに比例して凹量が增加する傾向 が明瞭にうかがえる。このことから，硬化時の樹脂の収 縮により凹が発生することが想定できるが，表 1 に示す カタログに示されている収縮率の大小との関係は希薄で あることも明確といえる。

一方ウレタン樹脂系塗床では, 凹部の梁さに比例して
絶対値は小さいが，凸量が增加する傾向が明瞭にうかが える。理由としてウレタン樹脂系塗床の場合には気泡が 抜けづらい性質があるため，施工時に混入した気泡が硬 化時に抜けきれず, ささらに硬化熱で膨張し塗床試料表面 が膨れたものと想定できる。なお単層のウレタン樹脂系 塗床の塗厚は通常約 $3 \mathrm{~mm}$ が限界亡言われているが，本実 験でも下地試料の凹部で総塗厚が $3 \mathrm{~mm}$ を越えた箇所に明 確に䐍れを生じ，その他の部分には膨れを生じていない ことから，通常認識されているウレタン樹脂系塗床の塗 厚の限界が確認されたとむいえる。

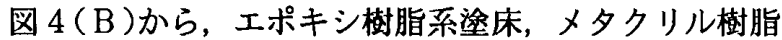
系塗床では，凹量に塗厚による明確な差は認められない ことがわかる。ウレタン樹脂系塗床では塗厚の増加に伴 い凸量がわずかに減少する傾向は見受けられるが，凸量 が大きくても0.153mmであり凹量の場合と比へて非常に 小さいことを考慮すると，明確な傾向之はいえない。以 上から塗厚を厚くすることで下地凹凸によって発生する 床表面凹凸量を小さくすることは期待できないといえる。

図 4(C)功, メタクリル樹脂系塗床では，凹部直径 が小さいほど凹量が大きくなる傾向がわずかにみられる が, エポキシ樹脂系塗床とウレタン樹脂系塗床では，両 者に明確な関係はみられないことがわかる。従って下地 の凹部直径とは無関係に，床表面に凹凸が発生するとい

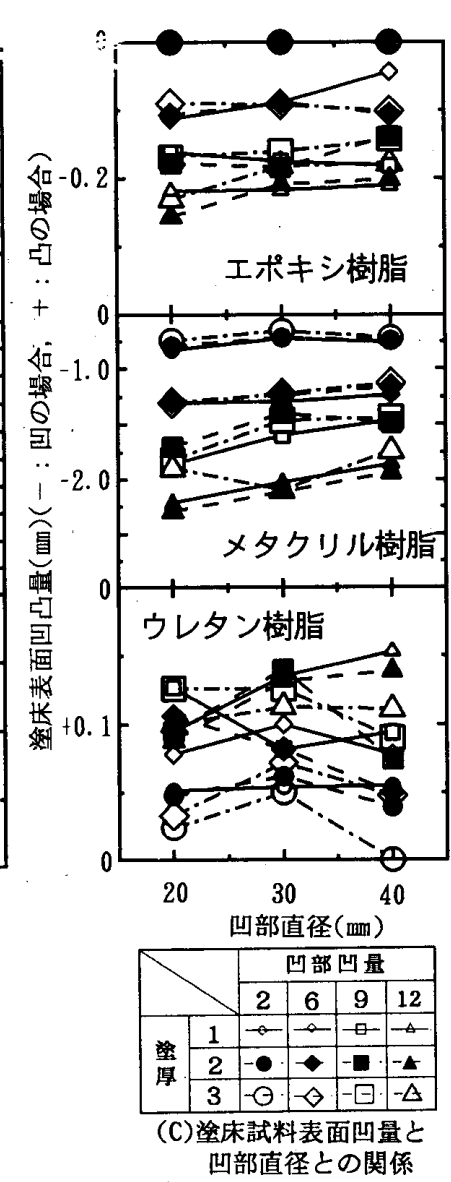
える。

以上より塗床では, 下地凹凸の影響を受け 塗床表面凹凸が発生す ることを確認できたと いえる。つまり塗床は 従来から言われてきて いるように，硬化前に はセルフレベリング性 を有する材料の効果で 平坦な表面を保持する か，下地修正の如何に 関わらず下地に凹凸が 存在する場合は，硬化 後の床表面に凹凸が生 じることが明白であり， 改めて下地の仕上げ精 度の重要性が確認でき たといえる。 また， 塗厚を厚くすることで 床表面凹凸量を小さく することはできないこ と，床表面凹凸は下地 凹凸の平面上の大きさ に関係なく発生するこ 
と,さらに下地の凹部の深さと床表面凹凸量との間には 比例的関係があることなど, 単純な下地凹凸を対象とし た場合の実験結果ではあるが，これまで明らかにされて いない，いくつかの重要な知見が得られたと考える。

なお 5.5.2における考察事項は敩密には本研究で設定 した範囲でいえることを付記する。

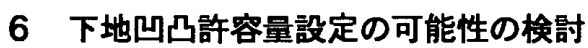

\section{1 許容量の必要性}

床表面に生じる凹凸を施工後に修正することは，様々 な点で効率が悪いだけでなく, 実際には非常に困難であ るといえる。ここであらかじめ床表面に要求される平滑 さの精度，すなわち床表面凹凸の限界値が設定でき，設 定した限界値以上の凹凸を発生させないために必要な下 地凹凸の許容量が設定できれば，下地凹凸に起因する床 表面凹凸発生の問題をより効率よく解決できると考えら れる。

以上の観点から本項では，作成した塗床試料および 5 . で得た知見を用いて，ある目的に対して限界となる凹凸 以下に床表面の平滑性を保持するために必要な下地凹凸 の許容量の設定をその可能性をむ含めて試みることとし た。

\section{2 床表面凹凸の評価の観点の設定}

床表面凹凸に起因する問題として，美観（見た目）の 低下，清掃性の低下，キャスター走行性などの低下，局 部磨耗を含む損傷の增大などが挙げられるが，本研究で は身近でかつ最も重要な問題のひとつといわれる，見た 目の観点からの評価を一例として試みることとした。

6.3 床表面凹凸の評価に関する検査

6.3.1 試料の設定および検查方法

4.で作成した 9 枚の塗床試料を用い, ひとつの塗床に つき 36 個, 計 108 個の塗床試料表面凹凸を検查試料とす ることとした。

検查における凹凸観察条件の概要を図 5 に示す。図に 示した条件は床の凹凸が最も目立つ観察条件のひとつと して, 著者らの一部による既往の研究成果をもとに設定 した ${ }^{2)}$ 。なお本研究の段階においては，観察条件を最も 目立つ条件とする必然性はなく，一定の条件であればよ いことを付記する。

検查手法は絶対判断による系列範ちゅう法とし, 塗床 試料を一枚づつ検査員に提示し，各凹凸ごとに凹凸の気 になる程度を表 2 に示した判断範ちゅうを用いて口頭で 答えさせることとした。

検查員は21歳から32歳までの正常な視力を有する成人 男女10名とした。

なお検查は室温 $20^{\circ} \mathrm{C} \pm 2{ }^{\circ} \mathrm{C}$, 湿度 $50 \% \pm 5 \% \mathrm{RH}$ 設定 した検查室で行った。

\section{3 .2 検查結果および考察}

検查結果の解析にあたり，叙床試料の種類ことに表面 の光沢, 色に違いがあるため, 塗床試料の種類ごとに解 析することとした。検查の分散分析結果を表 3 に示す。

エポキシ樹脂系塗床，メタクリル樹脂系塗床では主効 果および個人差の分散比はと屯に危険率 $1 \%$ で有意であ るが，個人差と比較して主効果の分散比および寄与率が きわめて大きいことから，本研究で用いた試料は十分に 美異のある刺激を与えていること，検查員には共通の判 断基準が存在していることなどが明白で，検查方法を含 め見た目の判断を求める検查として有効であったといえ る。

一方ウレタン樹脂系塗床では奇与率は主効果, 個人差 ともに有意であるが，主効果と比較して個人差の分散比 の方が大きいこと, 寄与率の值に明瞭な差のないことが わかる。主な原因として, 検查に用いたウレタン樹脂系 塗床の凸量が $0 \mathrm{~mm} \sim 0.153 \mathrm{~mm}$ と小さく， かつ塗床表面全

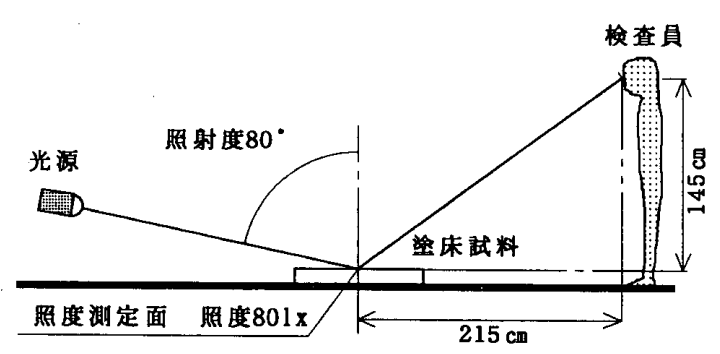

図 5 床表面凹凸観察条件の概要

表 2 検查条件の概要

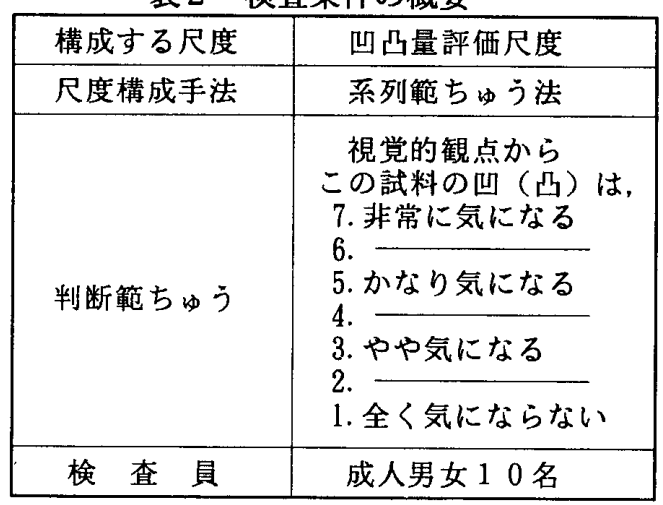

表 3 分散分析結果

\begin{tabular}{|l|l|r|c|}
\hline & & 分散比 & 寄与率(\%) \\
\hline \multirow{2}{*}{ エポキシ樹脂 } & 主効果 & 31.22 & 66.64 \\
\cline { 2 - 4 } & 個人差 & 19.94 & 10.74 \\
\hline \multirow{2}{*}{ ×タクリル樹脂 } & 主効果 & 55.28 & 77.00 \\
\cline { 2 - 4 } & 個人差 & 24.16 & 8.45 \\
\hline \multirow{2}{*}{ ウレタン樹脂 } & 主効果 & 9.95 & 37.40 \\
\cline { 2 - 4 } & 個人差 & 19.39 & 19.75 \\
\hline
\end{tabular}

*分散比はすべて危険率 $1 \%$ で有意 
体に小さな気泡によるあれが発生しているため，検查員 が凸の気になり具合に関して，十分に差異のある判断を 下すことができなかったことが考えられる。

以上よりエポキシ樹脂系塗床, メタクリル樹脂系症床 の見た目の評価に関する尺度のみを尺度構成理論 ${ }^{33}$ に基 ついて構成し, 以降エポキシ樹脂系塗床とメタクリル樹 脂系塗床を例として，下地凹凸の許容量設定の可能性を 検討することとした。

\section{4 下地凹凸許容量設定の可能性に関する基礎的考察}

図 6 に構成した評価尺度之塗床試料表面凹量之の関係 を示す。全体として塗床試料表面凹量の増加に比例して 評価が低くなることが明確にわかる。つまり, 塗床表面 凹凸量と不都合さの程度との定量的関係を求めることの 可能性を確認できたといえる。

さらに例えばエポキシ樹脂系塗床では, 図6に一点鎖 線で示すように仮に判断範ちゅう(3)の”やや気になる” を塗床試料表面凹量の見た目の許容限界とした場合, 塗 床試料表面凹量の限界值は約 $0.1 \mathrm{~mm}$ 之推定できる。ここ で5.5.2に示した図 4（A）を用いて，一点鎖線に示す ように塗床試料表面凹量を0.1m的以下に抑えるには，下 地試料の凹部の深さを約 $6 \mathrm{~mm}$ 以下にすればよい，つまり 許容量は $6 \mathrm{~mm}$ であると推定できる。
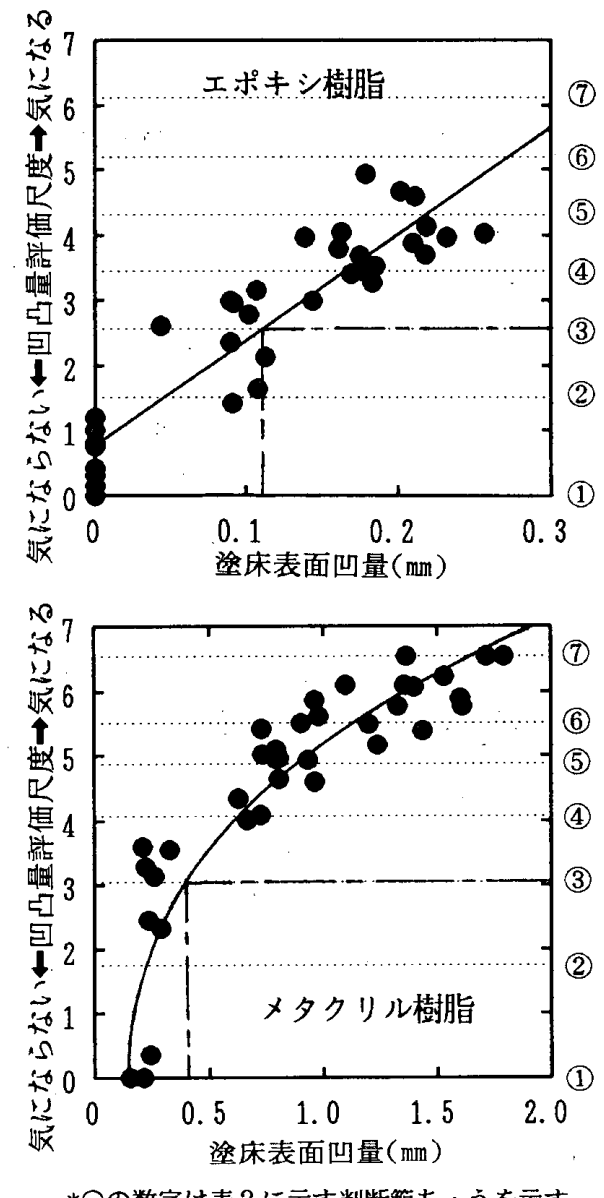

*○の数字は表 2 に示す判断䡉ちゅうを示す
同様にメタクリル樹脂系塗床の場合，塗床試料表面凹 量の限界值は図 6 より約0.4mm 推定でき, 図 4(A) より下地試料の凹部の樑さの許容量は約 $3 \mathrm{~mm}$ と推定でき る。

なお上述の考察は可能性の検討を主眼としているため 図 4（A），図6における中心傾向を用いて行ったが必 要であれば同様の方法で任意のばらつきをも含めて行え ることを付記する。

以上より，見た目の観点から下地凹凸許容量を設定で きる可能性があることを例示できたと考える。また本研 究で示した手法を応用することで，様々な性能項目ごと に下地凹凸の許容量を設定できる可能性を示したといえ る。

なお本研究でも基本的に明らかにしたとおり，下地凹 凸量之；床表面凹凸量の関係は樹脂により異なること， 評価の観点によっては床表面凹凸に対する評価が色，光 沢，かたさなどの凹凸以外の要因によっても左右される ことが考えられることなどの理由から，実際の下地凹凸 の許容量は，厳密には塗床の種類ごに設定されるべき であり, さらに凹凸以外の塗床表面の諸性状をも加味し た設定がなされるべきいえる。

\section{7 結}

塗床においては下地凹凸の影響を受け表面に凹凸を生 じると考えるへきざあること，また下地凹凸と床表面凹 凸との間には相関関係が認められることを明らかにした。 さらに床表面凹凸の限界值が要求される性能項目およ び性能の程度との関連の中で, 何らかの方法で設定でき れば，下地凹凸の許容量を設定できることの可能性を示 した。実際の塗床を対象とした場合，単純化した本研究 の成果，特に絶対量に関してはさらなる厳密な検討を必 要とするが, 塗床の精緻化の要求が早急な現状において, 本研究の成果が床表面凹凸に大きな影響を与える下地の 表面精度のあり方の検討の基礎的な知見となることを望 みたい。

むすびに当たり，塗床の実情に関して貴重な情報を提 供していただいた日本塗床工業会の皆様，さらに資料の 提供，塗床の施工にご協力をいただいた島建材株式会社 の皆様に謝意を表します。

\section{考文埱}

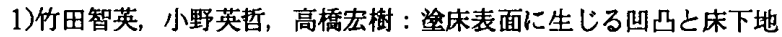
の凹凸との関係の基碳的研究, 日本建築学会大会学術講演梗概集 $\mathrm{A}$, pp. $615 \sim 616,1993$ 年9月

2)小野英哲，柳澤忠義，三上貴正，横山裕，高木直 : 視覚的観点か らみた建筑物床仕上面の凹凸の評価方法に関する研究，日本建筑学 会大会学術講演梗概集 A，pp. 717～718，1987年9月

3)J.P.Guilford著，秋重議治鑑訳：精神測定法，培風馆，1969年 (1994 年 2 月 10 日原稿受理, 1994 年 8 月 5 日採用決定) 